JPdK Volume 1 No 1 Tahun 2019 Halaman 25-37

JURNAL PENDIDIKAN dan KONSELING

Research \& Learning in Primary Education

\title{
Penerapan Model Kooperatif Think Talk Write Untuk Meningkatkan Keterampilan Menulis Karangan Narasi Pada Siswa Sekolah Dasar
}

\author{
Demi Warny Dery ${ }^{1}$, Putri Hana Pebriana ${ }^{2}$, Kasman Edi Putra ${ }^{3}$ \\ Program Studi Pendidikan Guru Sekolah Dasar \\ Fakultas Ilmu Pendidikan \\ Universitas Pahlawan Tuanku Tambusai \\ Email: delmiwarny@gmail.com
}

\begin{abstract}
Abstrak
Penelitian ini bertujuan dapat meningkat keterampilan menulis karangan narasi pada mata pelajaran Bahasa Indonesia di kelas III Sekolah Dasar Negeri 015 Tandun melalui penerapan model kooperatif tipe Think Talk Write. Penelitian ini dilatar belakangi oleh rendahnya hasil keterampilan menulis karangan narasi yang tidak mencapai nilai KKM yang ditetapkan sekolah yaitu 75.Penelitian ini merupakan penelitian tindakan kelas.Subjek penelitian ini adalah siswa kelas III tahun ajaran 2018-2019 dengan jumlah siswa sebanyak 20 orang.Objek dalam penelitian ini adalah model pembelajaran kooperatif tipe Think Talk Write dan keterampilan menulis karangan narasi. Penelitian ini terdiri dari empat tahapan tiap siklus yaitu: perencanaa, pelaksanaan, pengamatan, dan refleksi. Penelitian ini dilakukan sebanyak 2 siklus yang masing-masing siklus terdiri dari dua kali pertemuan.Pengumpulan data dalam penelitian ini menggunakan dokumentasi dan tes.Berdasarkan hasil analisis data dapat diketahui bahwa terjadinya peningkatan keterampilan menulis karangan narasi pada mata pelajaran Bahasa Indonesia.Sebelum tindakan ketuntasan hasil keterampilan menulis karangan siswa hanya mencapai $25 \%$, lalu pada siklus I pertemuan I meningkat menjadi $30 \%$, siklus I pertemuan II meningkat menjadi $45 \%$ dan pada siklus II pertemuan I meningkat menjadi 70\% kemudian siklus II pertemuan II meningkat lagi menjadi 85\%.Dengan demikian dapat disimpulkan bahwa Penerapan Model Kooperatif Tipe Think Talk Write dapat Meningkatkan Keterampilan Menulis Karangan Narasi Pada Siswa Sekolah Dasar.
\end{abstract}

Kata Kunci: Model Think Talk Write, Keterampilan Menulis Karangan Narasi.

\begin{abstract}
The purpose of this research is to improve narrative essay writing skill in learning Indonesia Language in grade III of SDN 015 Tandun through the application of cooperatif model Think Talk Write tipe.the background of this research is because of the low results of narrative essay writing skill which is under the standard of KKM, that is 75. This research is classroom action research. The subjeck of the research is the grade III students in academic year 2018/2019 with 20 students. The object of the research is cooperative model Think Talk Write type and narrative essay writing skill. this research consists four of four stage, every cycle which are: planning, implementation, observations and reflektion type. The research is conducted by 2 cycles, each cycles consists of reflektion 2 cycles of two meeting. Data collecction in this research.Uses documentation and tes. Based on the results of data analysis is know that there is the improving of narrative essay writing skill in indonesialanguage skill. Before the completion of the results of narrative essay writing skill only reached $25 \%$, then
\end{abstract}


the first cycle. First meeting increases to $30 \%$, first cycle second meeting increses to $45 \%$ and and on the second cycle first meeting increases to become $70 \% \%$ then second cycle. second meeting encreases to become $85 \%$. Then we can inter that the implementation of cooperative model Think Talk Write can improve narrative essay writing skill in students primary school.

Keywords: Thnik Talk Write Model, Narrative Essay Writing Skill.

\section{PENDAHULUAN}

Pendidikan dipandang sebagai salah satu aspek yang memiliki peranan pokok dalam membentuk generasi mendatang. Dengan pendidikan diharapkan dapat menghasilkan manusia yang berkualitas dan bertanggung jawab serta mampu mengantisipasi masa depan. Pendidikan dalam maknanya yang luas senantiasa menstimulir, menyertai dan membimbing perubahan-perubahan dan perkembangan hidup serta kehidupan manusia.

Menurut (Ihsan, 2010:2-3) Pendidikan bagi kehidupan umat manusia merupakan kebutuhan mutlak yang harus dipenuhi sepanjang hayatnya agar sejalan dengan cita-cita untuk maju, sejahtera dan bahagia menurut konsep pandangan hidup mereka.Maka pendidikan menjadi sarana yang paling utama dalam kehidupan manusia itu sendiri.

Undang-Undang Sistem Pendidikan Nasional No. 20 Tahun 2003, disebutkan bahwa pendidikan adalah usaha sadar dan berencana untuk mewujudkan suasana belajar agar peserta didik aktif mengembangkan potensi dirinya terhadap kekuatan spiritual keagamaan, pengendalian, kepribadian, kecerdasan, akhlak mulia serta keterampilan yang diperlukan dirinya, masyarakat, bangsa dan Negara.

Mengenai pendidikan, Soyomukti (2016:21) berpendapat bahwa pendidikan merupakan "Proses untuk memberikan manusia berbagai macam situasi yang bertujuan memberdayakan dirinya". Peraturan pemerintah nomor 32 tahun 2013 pasaal 77G (1) menyatakan bahwa struktur kurikulum pendidikan anak usia dini berisi program-program pengembangan nilai agama dan moral, motorik, kognitif, bahasa, Sosial emosional, dan seni. Salah satu mata pelajaran yang terdapat dalam kurikulum pendidikan Indonesia adalah pembelajaran Bahasa Indonesia.

Bahasa Indonesia menurut Doyin (2010: 10) adalah pembelajaran yang penting untuk memperkenalkan kebudayaan Indonesia sekaligus sebagai sarana untuk mengenal lebih lanjut mengenai pembelajaran lain. Permendikbud nomor 23 tahun 2006 menyatakan bahwa tujuan pembelajaran bahasa membentuk manusia Indonesia yang kebangsaan cinta tanah air. Adapun standar kompetensi lulusan mata pelajaran Bahasa Indonesia menurut Permendiknas nomor 23 tahun 2006 meliputi aspek mendengarkan, berbicara, membaca, dan menulis.

Pembelajaran Bahasa Indonesia diarahkan untuk meningkatkan kemampuan peserta didik untuk berkomunikasi dalam bahasa Indonesia dengan baik dan benar, baik secara lisan maupun tulis, serta menumbuhkan apresiasi terhadap hasil karya kesastraan manusia Indonesia.

Adapun tujuan dari pembelajaran Bahasa Indonesia di Sekolah Dasar, Peraturan Menteri Pendidikan Nasional No. 22 Tahun 2006 tentang Standar Isi menyebutkan bahwa mata pelajaran Bahasa Indonesia adalah agar peserta didik memiliki kemampuan sebagai berikut: 
1. Berkomunikasi secara efektif dan efisien sesuai dengan etika yang berlaku, baik secara lisan maupun tulis.

2. Menghargai dan bangga menggunakan Bahasa Indonesia sebagaimana bahasa persatuan dan bahasa Negara.

3. Memahami Bahasa Indonesia danmenggunakannya dengan tepat dan keratif untuk berbagai tujuan.

4. Menggunakan Bahasa Indonesia untuk meningkatkan kemampuan intelektual serta kematangan emosionaldan sosial.

5. Menikmati dan memanfaatkan karya sastra untuk memperluas wawasan, memperhalus budi pekerti, serta meningkatkan pengetahuan dan kemampuan berbahasa.

6. Menghargai dan membanggakan sastra Indonesia sebagai khasanah budaya bangsa dan intelektual manusia Indonesia.

Berdasarkan tujuan tersebut dapat disimpulkan bahwa pembelajaran bahasa di Sekolah Dasar diharapkan peserta didik mendapat bekal yang matang untuk mengembangkan dirinya dalam pendidikan berikutnya dan hidup bermasyarakat. Dalam bidang pengetahuan peserta didik memiliki pemahaman dasar-dasar kebahasaan terutama bahasa baku serta mempunyai sikap positif terhadap Bahasa Indonesia.

Salah satu aspek dalam pembelajaran Bahasa Indonesia yang harus dikuasai peserta didik adalah menulis, "Menulis merupakan salah satu dari empat keterampilan berbahasa (mendengarkan, berbicara, membaca, dan menulis. Menulis merupakan suatu proses bagaimana mengkomunikasikan ide kepada orang lain dengan baik, sehingga orang lain dapat memahami apa yang disampaikan melalui tulisan"(Tarmizi, 2013:12).

Keterampilan pada pembelajaran Bahasa Indonesia siswa diharapkan mampu menggunakan berbagai jenis wacana tulis untuk menggungkapkan pikiran, perasaan, dan informasi dalam bentuk teks.Kegiatan menulis tersebut dapat digolongkan dalam menulis kreatif atau menulis faktual.Salah satu kegiatan menulis kreatif adalah menulis karangan narasi.Karangan yang dibahas dalam penelitian ini adalah jenis karangan narasi.

Alasan memilih jenis karangan narasi ini karena sesuai dalam silabus pembelajaran kelas III yaitu Standar Kompetensi: Mengungkapkan pikiran, perasaan, dan informasi dalam karangan sederhana dan puisi. Kompetensi Dasar: Menulis karangan sederhana berdasarkan gambar seri menggunakan pilihan kata dan kalimat yang dengan memperhatikan ejaan, huruf kapital, dan tanda titik. Serta rata-rata nilai siswa dalam pembelajaran menulis karangan narasi masih rendah.

Berdasarkan observasi yang dilakukan oleh peneliti pada tanggal 26 Februari 2019 di SDN 015 Tandun Kabupeten Rokan Hulu, berdasarkan data nilai pada mata pelajaran Bahasa Indonesia materi keterampilan menulis karangan narasi yang diperoleh peneliti dari guru kelas III SDN 015 Tandun pada semester genap Tahun Ajaran 2018/2019 mengalami permasalahan.Dari 20 siswa, yang tuntas hanya 5 siswa (25\%) dan tidak tuntas berjumlah 15 siswa (75\%).

Data tersebut memperlihatkan masih banyak siswa yang belum mencapai Kriteria Ketuntasan Minimal (KKM). terdapat beberapa masalah yang menyebabkan rendahnya keterampilan menulis karangan narasi siswa yaitu keterbatasan menggunakan ejaan, , model pembelajaran menulis tidak berorientasi pada siswa, ketidakmampuan siswa dalam 
menentukan topik, ketidak mampuan siswa dalam membentuk judul, ketidakmampuan siswa dalam menentukan bentuk karangan, kurangnya penggunaan diksi atau pilihan kata, ketidakmampuan siswa menyusun kerangka karangan, ketidakmampuan guru membangkitkan keaktifan siswa, ketidakmampuan guru membimbing siswa saat siswa mengerjakan tugas menulis karangan narasi serta ketidakmampuan guru dalam menemukan dan menerapkan model pembelajaran yang tepat dalam mengajar materi manulis karangan narasi.

Berdasarkan permasalahan yang telah dipaparkan, maka perlu dilakukan perbaikan dalam proses pembelajaran. Salah satunya dengan menggunakan model yang sesuai dengan menulis karangan narasi. Peneliti mencoba memberikan rekomendasi pada perbaikan proses pembelajaran khususnya pada materi menulis karangan narasi dengan menggunakan model Think Talk Write.

Berdasarkan latar belakang tersebut maka peneliti merekomendasikan penelitian dengan judul "Penerapan Model Think Talk Write Untuk Meningkatkan Katerampilan Menulis Karangan Narasi Pada Siswa Sekolah Dasar”

Berdasarkan latar belakang yang telah diuraikan di atas, maka terdapat beberapa masalah dalam pembelajaran, sebagai berikut:

1. Keterbatasan menggunakan ejaan.

2. Model pembelajarn menulis tidak berorientasi pada siswa,

3. Ketidakmampuan siswa dalam menentukan topik,

4. Ketidak mampuan siswa dalam membuat judul,

5. Kurangnya penggunaan diksi atau pilihan kata,
6. Kesulitan dalam mengungkapkan ide dan imajinasinya dalam bentuk tulisan.

Berdasarkan identifikasi masalah yang telah diuraikan, dapat dirumuskan permasalahan dalam Penelitian Tindakan Kelas (PTK).Adapun rumusan masalah yaitu "Apakah Penerapan Model Think Talk Write Dapat Meningkatkan Keterampilan Menulis Karangan Narasi di Kelas III SDN 015 Tandun?"

\section{MTODOLOGI PENELITIAN}

Penelitian ini menggunkan metode kualitatif yang berjenis Penelitian Tindakan Kelas (Class Action Research). Arikunto ( Iskandar, 2009:20) mengatakan bahwa, "Penelitian Tindakan Kelasmerupakan suatu pencermatan terhadap kegiatan pembelajaran berupasebuah tindakan, yang sengaja dimunculkan dan terjadi dalam sebuah kelas secarabersamaan". Selain itu, Iskandar (2009:21) juga menyatakan bahwa: "PenelitianTindakan Kelas adalah suatu kegiatan penelitian ilmiah yang dilakukansecara rasional, sistematis dan empiris reflektif terhadap berbagai tindakan yangdilakukan oleh guru atau dosen (tenaga pendidik), kolaborasi (tim peneliti) yangsekaligus sebagai peneliti, sejak disusunnya suatu perencanaan sampai penilaianterhadap tindakan nyata di dalam kelas yang berupa kegiatan belajar mengajar,untuk memperbaiki dan meningkatkan kondisi pembelajaran yang dilakukan".

Subjek penelitian adalah seluruh siswa kelas III SDN 015 Tandun Kabupaten Rokan Hulu dengan jumlah siswa 20 orang, yang terdiri dari 9 orang siswa laki-laki dan 11 orang siswa perempuan. Penelitian tindakan kelas ini dilaksanakan dua siklus.Siklus pertaman 
dilaksanakan dua kali pertemuan dan siklus kedua juga dua kali pertemuan.Alokasi waktu pada setiap pertemuan 70 menit. Pelaksanaan masingmasing siklus mengikuti tahap-tahap perencanaan,tindakan,observasi,dan refleksi.

Berhasil tidaknya penelitian dilakukan dapat diketahui dari data yang diperoleh. Terkait dengan itu, untuk memperoleh data dalam menjawab masalah penelitian dapat dilakukan dengan menggunakan instrumen penelitian yaitu sebuah alat bantu yang dipilih peneliti dalam kegiatan pengumpulan data, agar kegiatan tersebut berjalan dengan sistematis. Arikunto (dalam Sarjana, 2010:43).Data penelitian yang digunakan dalam penelitian tindakan kelas ini berupa observasi dan tes sebagai metode utama untuk memperoleh data.

Instrumen penelitian adalah alat atau fasilitas yang digunakan peneliti dalam mengumpulkan data agar pekerjaannya lebih mudah dan hasilnya lebih baik, dalam arti lebih cermat, lengkap dan sistematis sehingga lebih mudah diolah.Agar penelitian ini dapat dilaksanakan dengan baik maka perlu dipersiapkan instrument penelitian. Adapun instrumen penelitian yang perlu dipersiapkan sebagai berikut:

1. Instrumen Perencanaan Pembelajaran berfungsi untuk menilai perencanaan pembelajaran peneliti menggunakan lembar instrumen perencanaan pembelajaran yang akan dinilai oleh obsever pada setiap pembelajaran siklus I dan siklus II.

2. Lembar Observasi berfungsi untuk menilai kegiatan yang dilakukan peneliti dalam melaksanakan penelitian, observer akan mengisi lembaran observasi yang mencatat kegiatan peneliti dari awal sampai akhir. Lembar observasi terbagi dua bagian yaitu lembar observasi aktivitas guru dan lembar observasi aktivitas siswa.

3. Rubrik penilaian karangan narasi berfungsi untuk mengetahui peningkatan keterampilan menulis karangan narasi siswa telah mencapai KKM atau belum, peneliti menggunakan rubrik penilaian menulis karangan narasi yang dibuat oleh peneliti.

Teknik pengumpulan data merupakan langkah yang paling strategis dalam penelitian karena tujuan utama dari penelitian adalah untuk mendapatkan data. Adapun teknik pengumpulan data yang akan diambil sebagai berikut:

1. Teknik Dokumentasi yang digunakan dalam penelitian ini adalah menganalisis RPP. Hasil dari dokumentasi ini digunakan untuk mendeskripsikan perencanaan pelaksanaan pembelajaran dengan penerapan model Think Talk Write.

2. Teknik Observasi digunakan untuk mengumpulkan data tentang aktivitas guru dan siswa ketika proses pembelajaran berlangsung dengan menggunakan penerapan model Think Talk Write.

3. Teknik Tes digunakan untuk mengumpulkan data tentang keterampilan menulis. Tes menggunakan test formatif berupa Lembar Tugas Siswa (LTS) yang diberikan kepada siswa untuk menulis karangan narasi yang akan dilaksanakan pada akhir pembelajaran siklus I dan II.

Analisis data yang digunakan dalam penelitian ini adalah analisis kuantitatif dan analisis kualitatif.Analisis kuantitatif digunakan untuk menganalisis nilai rata-rata dan persentase skor hasil keterampilan menulis karangan narasi siswa. Sedangkan analisis kualitatif 
digunakan untuk menganalisis lembar observasi kegiatan siswa dan guru saat proses pembelajaran. Berikut penjelasannya:

1. Analisis Kuantitatif

a. Ketuntasan Belajar Individu

Adapun pedoman rubrik yang digunakan dalam penelitian keterampilan menulis karangan narasi siswa SDN 015 Tandun.Peneliti membuat rubrik penilaian karangan narasi untuk menilai hasil karangan narasi siswa. Adapun aspek yang dinilai ada 3 yaitu :

1) Ejaan.

2) Tanda baca.

3) Pilihan kata.

Siswa dikatakan tuntas apabila nilainya mencapai KKM atau lebih tinggi dari KKM yaitu 75. Untuk menentukan ketuntasan yang dicapai siswa peneliti menggunakan rumus yang digunakan yaitu:

KBSI

$=\frac{\text { Skor yang diperoleh siswa }}{\text { Skor Maksimum }} \times 100$

Keterangan :

KBSI = Ketuntasan Belajar Siswa Secara Individu

b. Ketuntasan Klasikal

Jika ketuntasan klasikal siswa telah mencapai $80 \%$ dari seluruh siswa, maka secara klasikal telah tercapai dengan baik. (Wardhani, 2007:25).

$$
K K=\frac{\text { Jumlah Siswa yang tuntas }}{\text { Jumlah Seluruh siswa }}
$$

Keterangan:

KK = Ketuntasan Klasikal

$$
\text { Adapun kriteria }
$$

proses pembelajaran

keterampilan menulis karangan narasi dapat dilihat pada tabel berikut:

Tabel 3.4

Interval Kriteria Ketuntasan Klasikal

\begin{tabular}{|c|l|l|}
\hline No & \multicolumn{1}{|c|}{ Interval } & \multicolumn{1}{|c|}{ Kategori } \\
\hline 1 & $90-100 \%$ & Baik Sekali \\
\hline 2 & $80-89 \%$ & Baik \\
\hline 3 & $70-79 \%$ & Cukup \\
\hline 4 & $60-69 \%$ & Kurang \\
\hline 5 & $<59 \%$ & Sangat Kurang \\
\hline
\end{tabular}

Sumber: (Riduan \& Sunarto, 2012:20)

\section{HASIL PENELITIAN DAN PEMBAHASAN}

\section{A. Deskripsi Pratindakan}

Sebelum dilakukan tindakan, peneliti melakukan observasi yaitu untuk mengetahui kemampuan siswa dalam menulis karangan narasi. Data dari observasi dan wawancara awal yang dilakukan dengan guru kelas III SDN 015 Tandun Kecamatan Tandun Kabupaten Rokan Hulu, bahwa hasil belajar siswa khususnya pada mata pelajaran Bahasa Indonesia terutama menulis karangan masih belum sesuai dengan yang diharapkan.

Berdasarkan data nilai keterampilan menulis karangan narasi yang diperoleh dari guru kelas III SDN 015 Tandun. Peneliti menganalisis data tersebut dengan KKM 75, dari 20 siswa hanya 5 siswa $(25 \%)$ orang siswa yang mencapai KKM. Sedangkan siswa yang tidak mencapai KKM sebanyak 15 siswa $(75 \%)$.

B. Deskripsi Hasil Tindakan Tiap Siklus

Perbandingan keterampilan menulis karangan narasi dengan menggunakan model Think Talk Write kelas III di SDN 015 Tandun pada siklus I dan siklus II terdapatnya peningkatan pada keterampilan 
menulis karangan narasi dengan menggunakan model Think Talk Write kelas III SDN 015 Tandun.

Diketahui bahwa nilai ratarata siswa pada siklus I pertemuan 1 sebesar 66 dengan kategori kurang (60\%-69\%) dan meningkat pada pertemuan 2 sebesar 73,95 dengan kategori cukup (70\%-79\%). Kemudian pada siklus II pertemuan 1 mengalami peningkatan menjadi 78,25 dengan kategori cukup (70\%$79 \%$ ). Lalu meningkat lagi pada pertemuan 2 menjadi 82,7 dengan kategori baik (80\%-89\%). Sedangkan presentase ketuntasan klasikal keterampilan menulis karangan narasi pada siklus I pertemuan 1 sebesar $30 \%$ dengan kategori kurang sekali $(<59 \%)$ dan pertemuan 2 meningkat menjadi $45 \%$ dengan kategori kurang sekali $(<59 \%)$.

Pada siklus II pertemuan 1 meningkat menjadi $70 \%$ dengan kategori cukup (70\%-79\%).Kemudian meningkat lagi pada pertemuan 2 sebesar $85 \%$ dengan kategori baik (80\%-89\%).Untuk mengetahui perkembangan keterampilan.

Berdasarkan tabel 4.7 menunjukkan bahwa nilai rata-rata kelas dari data awal 63,6 meningkat pada siklus I pertemuan 1 sebesar 66 . Kemudian meningkat lagi pada pertemuan 2 menjadi 73985. Siklus II pertemuan 1 sebesar 78,25. Lalu meningkat pada pertemuan 2 menjadi 82,7 . Begitu juga dengan ketuntasan secara klasikal dari data awal 25\% meningkat pada siklus I pertemuan 1 sebesar $30 \%$ dan pada pertemuan 2 menjadi $45 \%$. Pada siklus II pertemuan 1 sebesasr $70 \%$ dan di pertemuan 2 meningkat lagi menjadi $85 \%$. Untuk mengetahui secara jelas peningkatan setiap tindakan dapat dilihat pada diagram dibawah ini :

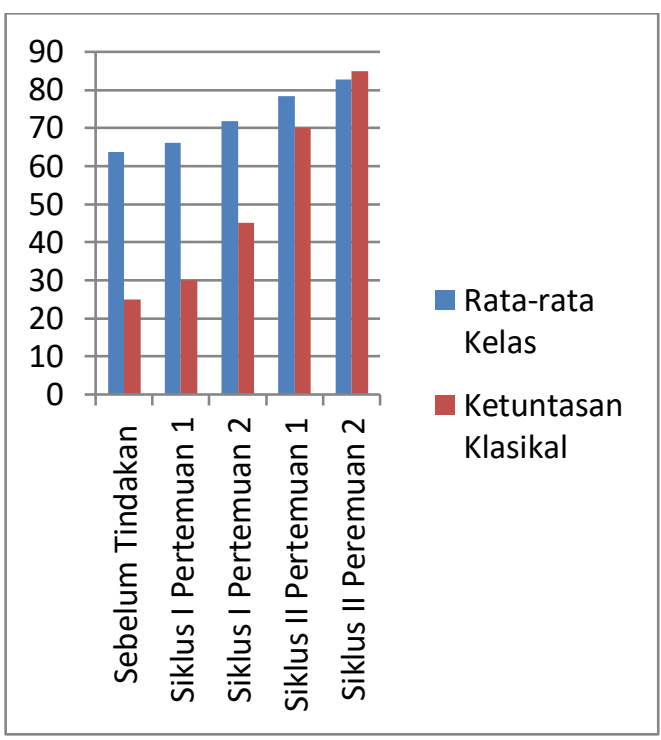

Gambar 4.1

(Diagram Perbandingan Nilai Siswa Pratindakan, Siklus I dan Siklus II)

Dilihat dari diagram di atas, dapat dilihat hasil keterampilan menulis karangan narasi baik secara klasikal maupun secara nilai rata-rata yang diperoleh siswa mengalami peningkatan.

Berdasarkan dari hasil penelitian yang telah dilakukan, maka beberapa hal yang akan dibahas terkait penelitian ini adalah:

\section{Perencanaan Peningkatan \\ Keterampilan Menulis Karangan Narasi Dengan Menggunakan Model Pembelajaran Kooperatif Think Talk Write}

Pada perencanaan pelaksanaan siklus I dan siklus II dalam pembelajaran Bahasa Indonesia pada materi menulis karangan pada siswa kelas III SDN 015 Tandun, perencanaan pembelajaran perlu dibuat 
sebagaimana yang dikemukakan (Suyatno, 2009) setiap guru pada satuan pendidikan berkewajiban menyusun RPP secara lengkap agar pembelajaran berlangsung secara inspiratif, menyenangkan, menantang, memotivasi peserta didik untuk berpartisipasi aktif, serta memberikan kreativitas, dan kemandirian sesuai dengan bakat dan minat.

Sebelum melakukan tindakan, peneliti terlebih dahulu harus membuat perencanaan karena proses pembelajaran perlu direncanakan, seperti yang dikemukakan (Arikunto, 2015) seorang guru dapat melakukan perencanaan dalam membuat PTK seperti merancang skenario pembelajaran, dan menetapkan indikator pencapaian, serta menyusun instrumen penelitian. Adapun perencanaan yang disusun oleh peneliti dalam penelitian ini adalah, menyusun silabus, menyusun RPP berdasarkan tahapan pada model kooperatif Think Talk Write yaitu,mempersiapkan lembar observasi aktivitas guru, mempersiapkan lembar observasi aktivitas siswa, meminta guru kelas yaitu ibu Suryani,S.Pd untuk menjadi observer I mengamati aktivitas guru dan meminta kesediaan teman sejawat yaitu Deti Ardiati untuk menjadi observer II mengamati aktivitas siswa, serta mempersiapkan lembar tugas siswa. Adapun komponenkomponen penting yang ada dalam rencana pembelajaran meliputi: identitas sekolah, standar kompetensi. kompetensi dasar, Indikator, tujuan pembelajaran, materi pokok, penerapan langkah- langkah model kooperatif Think Talk Write, sumber pembelajaran, dan penilaian. Berdasarkan dari penilaian yang dilakukan oleh observer I terhadap perencanaan yang dilakukan oleh peneliti pada siklus I adalah persiapan yang dilakukan oleh guru praktisi seperti kesesuaian antara indikator dengan standar kompetensi dan kompetensi dasar sudah sesuai, kemudian pemilihan materi ajar telah sesuai dengan tujuan pembelajaran, pemilihan materi ajar telah sesuai dengan karakteristik peserta didik, serta kesesuaian antara pemilihan materi ajar dengan alokasi waktu juga sudah sesuai.

Secara keseluruhan, penilaian dalam perencaan ini sudah lumayan baik meskipun masih perlu diperbaiki lagi. Sedangkan pada siklus II penilaian yang diberikan oleh observer I terhadap perencanaan yang telah dilakukan adalah kesesuaian antara indikator dengan standar kompetensi dan kompetensi dasar nya sudah sesuai, kemudian pemilihan materi ajar telah sesuai dengan tujuan pembelajaran, pemilihan materi ajar telah sesuai dengan karakteristik peserta didik, serta kesesuaian antara pemilihan materi ajar dengan alokasi waktu juga sudah sesuai.

Skenario pembelajaran telah sesuai dengan metode yang digunakan yaitu model kooperatif Think Talk Write.Berdasarkan penilaian tersebut dapat disimpulkan bahwa perencanaan yang dilakukan oleh peneliti pada siklus II ini sudah jauh lebih baik daripada siklus sebelumnya.

2. Proses Pembelajaran Bahasa Indonesia Pada Materi Menulis 


\begin{abstract}
Karangan Narasi Dengan Menggunakan Model Kooperatif Think Talk Write

Berdasarkan hasil

pelaksanaan pada siklus I, pembelajaran masih belum maksimal, masih banyak terdapat siswa yang belum tuntas pada indikator penggunaan tanda baca.Ini dikarenakan kurangnya pengawasan guru terhadap siswa ketika siswa sedang mengerjakan tugas menulis karangan, siswa tergesa-gesa membuat karangan narasi karena penggunaan waktu yang tidak maksimal dan ketika berkelompok sebagian siswa cenderung bercerita dan meribut daripada mengerjakan tugas karangan yang diberikan.Kemudian penyebab lainnya adalah siswa masih bersifat pasif ketika pembelajaran berlangsung, maksudnya siswa masih belum berani mengemukakan pendapatnya ketika guru memberikan pertanyaan seputar materi yang diajarkan.

Keterampilan menulis siswa masih rendah ketika menuangkan ide, dan juga ketika menulis karangan narasi juga masih belum sesuai dengan aspek-aspek dalam penilaian keterampilan menulis.Dalam hal ini, guru perlu melakukan bimbingan yang lebih terhadap siswa, agar siswa merasa nyaman sehingga berani menyampaikan ide dan pendapatnya terkait pembelajaran.

Pada siklus II ini sudah berjalan lebih baik daripada siklus sebelumnya. Hal ini ditandai dengan siswa sudah lebih memperhatikan guru ketika guru menyampaikan materi pelajaran, siswa juga sudah lebih aktif dalam
\end{abstract}

proses pembelajaran dan berani mengemukakan pendapatnya atau menjawab pertanyaan yang diberikan oleh gurunya. Pada siklus II ini siswa juga sudah mampu dalam mengerjakan tugas pada pelajaran Bahasa Indonesia pada materi menulis karangan narasi sudah mengalami peningkatan.

Berdasarkan hasil pelaksanaan pada siklus I hingga siklus II ini, keterampilan menulis siswa pada pembelajaran Bahasa Indonesia materi menulis karangan narasi dengan menggunakan model kooperatif Think Talk Write mengalami peningkatan pada siswa kelas III SDN Negeri 015 Tandun.

3. Peningkatan Keterampilan Menulis Karangan Narasi Siswa Dengan Menggunakan Model Kooperatif Think Talk Write

Berdasarkan dari data sebelum diterapkannya model kooperatif Think Talk Write, diketahui bahwa hasil belajar siswa terhadap pelajaran Bahasa Indonesia pada materi menulis karangan narasi masih kurang, yaitu dengan rata-rata 63,6, sedangkan ketuntasan klasikalnya yaitu $25 \%$. Hal ini disebabkan karena selama ini guru masih menggunakan metode lama, dan pembelajaran hanya terfokus pada guru sedangkan siswa hanya mencatat pada buku catatan, sehingga siswa menjadi merasa bosan.

Hasil keterampilan menulis karangan siswa pada siklus I mengalami peningkatan dari sebelumnya yaitu dari 63,6 menjadi 73,95. Pada siklus ke II, rata-rata hasil belajar siswa adalah 82,7. Dari 20 orang, sebanyak 17 orang telah mencapai ketuntasan secara 
individual, sedangkan ketuntasan siswa secara klasikal telah mencapai $85 \%$ atau hanya 3 orang saja yang tidak tuntas. Secara klasikal, hasil belajar siswa telah mencapai kriteria yang telah ditetapkan. Berdasarkan ketuntasan klasikal di atas, dapat disimpulkan bahwa nama siswa yang tidak tuntas pada siklus II ini sama dengan nama siswa yang tidak tuntas pada siklus pertama, yaitu DSH dengan nilai pada siklus I adalah 67, dan nilai pada siklus ke II adalah 673. Kemudian ada HHP dengan nilai pada siklus I adalah73, dan nilai pada siklus II adalah 73. Ketiga ada NH dengan nilai pada siklus I adalah 60 dan pada siklus kedua adalah 60 .

Penyebab siswa tersebut tidak tuntas adalah karena pada saat pembelajaran berlangsung mereka asyik bermain dibangku mereka yang jaraknya berdekatan, kemudian kepercayaan diri siswa tersebut juga rendah, mereka tidak mau ketika diminta oleh guru untuk menyampaikan pendapat.Selain itu, penyebab hasil belajar siswa dapat dipengaruhi oleh beberapa faktor. Hal ini juga di ungkapkan oleh (Daryanto, 2009) bahwa hasil belajar siswa dipengaruhi oleh faktor internal dan eksternal, yaitu:

Faktor internal:

a) Faktor jasmaniah, meliputi: faktor kesehatan dan cacat tubuh.

b) Faktor psikologis, meliputi: intelegensi, perhatian, minat, bakat, motif, kematangan, dan kesiapan.

c) Faktor kelelahan

Faktor eksternal: a) Faktor keluarga meliputi: cara orang tua mendidik, relasi antara anggota keluarga, suasana rumah, keadaan ekonomi keluarga, pengertian orang tua, dan latar belakang kebudayaan.

b) Faktor Sekolah meliputi: metode mengajar, kurikulum, hubungan guru dan siswa, hubungan siswa dan siswa, disiplin sekolah, alat pelajaran, waktu sekolah, Standar pelajaran di atas ukuran, keadaan gedung, metode belajar, dan tugas rumah.

Dalam meningkatkan keterampilan menulis karangan narasi siswa, pemilihan model pembelajaran yang tepat sangat berpengaruh terhadap hasil belajar siswa.Salah satu pemilihan model yang tepat untuk pembelajaran Bahasa Indonesia berdasarkan hasil tindakan yang telah dilakukan, model kooperatif Think Talk Write memberikan dampak positif terhadap keterampilan menulis karangan narasi siswa.

Berdasarkan hasil penelitian ini membuktikan bahwa hipotesis jika model kooperatif Think Talk Write diterapkan, maka keterampilan menulis karangan narasi pada siswa kelas III SD Negeri 015 Tandun meningkat.

\section{SIMPULAN}

Berdasarkan hasil analisis data, proses dan hasil keterampilan menulis karangan narasi siswa dengan menggunakan model Think Talk Write pada siklus I dan siklus II telah mencapai sasaran yaitu adanya peningkatan keterampilan menulis karangan narasi siswa kelas III SDN 015 Tandun, rata-rata 
siswa pada pratindakan adalah 63,6 dengan kategori kurang (60\%-69\%). Pada siklus I pertemuan 1 sebesar 66 dengan kategori kurang (60\%-69\%) dan meningkat pada pertemuan 2 sebesar 71,85 dengan kategori cukup (70\%-79\%). Kemudian pada siklus II pertemian 1 mengalami peningkatan menjadi 78,35 dengan kategori cukup (70\%-79\%). Lalu meningkat lagi pada pertemuan 2 menjadi 82,8 dengan kategori baik (80\%-89\%). Sedangkan presentase ketuntasan klasikal keterampilan menulis karangan narasi pratindakan adalah 25\% (5 siswa dari 20 siswa) dengan kategori kurang sekali $(<59 \%)$. Pada siklus I pertemuan 1 sebesar $30 \%$ (6 siswa dari 20 siswa) dengan kategori kurang sekali $(<59 \%)$ dan pertemuan 2 meningkat menjadi 45\% (9 siswa dari 20 siswa) dengan kategori kurang sekali $(<59 \%)$. Pada siklus II pertemuan 1 meningkat menjadi 70\% (14 siswa dari 20 siswa) dengan kategori cukup (70\%-79\%). Kemudian meningkat lagi pada pertemuan 2 sebesar $85 \%$ (17 siswa dari 20 siswa) dengan kategori baik (80\%-89\%).

Berdasarkan hasil penelitian di atas, maka saran peneliti yang berhubungan dengan penelitian ini adalah sebagai berikut:

1. Bagi guru, dalam menerapkan model pembelajaran koperatif Think Talk Write diharapkan membiasakan siswa belajar melalui kegiatan kelompok agar keterampilan menulis karangan narasi siswa meningkat. Guru juga diharapkan untuk memperhitungkan pembagian waktu dengan tepat dan cukup agar siswa memiliki waktu yang cukup untuk menulis karangan narasi.

2. Bagi sekolah, agar dapat meningkatkan keterampilan menulis karangan dan menjadi acuan pembelajaran dengan menggunakan model kooperatif Think Talk Write dan model pembelajaran lainnya seperti gambar dan video dengan memfasilitasi guru agar bisa menambah pengetahuannya dan memotivasi guru untuk bisa meningkatkan keterampilan menulis karangan narasi siswa. Sekolah juga harus mengawasi kegiatan guru di kelas karena tidak semua guru menggunakan jam pembelajaran dengan benar.

3. Bagi peneliti selanjutnya yang tertarik meneliti keterampilan menulis karangan narasi siswa dengan model pembelajaran kooperatif Think Talk Write sebagai bahan penelitiannya harus memahami dengan sungguhsungguh langkah-langkah yang terdapat pada model pembelajaran Think Talk Write agar pembelajaran dapat berjalan sesuai yang diharapkan dan agar menambah observer lebih dari satu orang karena yang diamati itu proses pembelajaran dan data yang diperoleh lebih valid.

\section{DAFTAR PUSTAKA}

Abbas.(2006). Pembelajaran Bahasa Indonesia Yang Efekyif di Sekolah Dasar. Jakarta: Dirjendikti

Ajeng, dkk. (2017). Peningkatan Keterampilan Menulis Puisi Melalui Model Pembelajaran Think Talk Write Pada Siswa Kelas $V$ SDN 01 Kalisoro Tawangmangu Karanganyer. Universitas Sebelas Maret. Surakarta : skripsi Tidak Dipublikasikan.

Ahsin, M.N. (2016). Peningkatan Keterampilan Menulis Karangan Narasi Dengan Menggunakan Media Audiovisual dan Metode Quantum Learning.Jurnal 
Refleksi Edukatika. Vol. 6 No 2 Juni 2016.

Aprinawati, I. (2015). Penerapan Teknik Parafase untuk Meningkatkan Kemampuan Menulis Puisi Bebas Siswa Kelas $V$ sekolah Dasar Negeri 016 Bangkinang.Lembaga Penelitian \& Pengabdian Masyarakat (LPPM) STKIP Pahlawan Tuanku Tambusai Riau.Volume 2, No. 1.

Azmussya'ni. (2014). Peningkatan Keterampilan Menulis Menggunakan Peningkatan Proses Dengan Media Gambar di SDN 3 Sakra. Jurnal Prima Edukasia. Volume 2- Nomor 1, 2014.

Arikunto, S. (2015).Penelitian Tindakan Kelas. Jakarta : PT Bumi Aksara (2014). Penelitian Tindakan Kelas.Jakarta : PT Bumi Aksara (2010). Manajemen Penelitian. Jakarta: Rineka Cipta.

Bukhari. (2010). Keterampilan Berbahasa Membaca dan Menulis. Banda Aceh: Yayasan Pena

Dalman.(2016). Keterampilan Menulis. Jakarta: Raja Persada.

Daryanto.(2009). Panduan Proses Pembelajaran.Jakarta: $\quad$ AV Publisher.

Denial.(2008). Menjadi Penulis Mulai dari Sekarang. Semarang: PT. Shindur.Press.

Didi dan Deni.(2012). Komunikasi Pembelajaran. Bandung: PT Remaja Rosdakarya

Doyin dan Wagiran. (2009). Bahasa Indonesia: Pengantar Penulis Karya Ilmiah. Semarang : UNNES PRESS

Fahriaty.(2013). Peningkatan Kemampuan Menulis Puisi Melalui Penerapan StrategiSugestopedia.Internationa $l$ Seminar on Quality and Affordable Education.Vol. 2 (2), hlm.2.

Finoza.(2009). Komposisi Bahasa Indonesia. Jakarta: Diksi Insan Mulia

Galuh. (2016). Peningkatan Keterampilan Menulis Pada Pembelajaran Bahasa Indonesia Melalui Model Think Talk Write Siswa Kelas IV Sdn 2 Jembatan Kembar. Universitas Mataram. Mataram : Skripsi Tidak Dipublikasikan.

Gie.(2002). Terampil Mengarang. Yogyakarta: Andi Offset.

Huda. (2015). Model-model Pengajaran dan Pembelajaran.Yogyakarta : Pustaka pelajar.

Ihsan.(2010). Dasar-dasar Kependidikan. Jakarta: Rineka Cipta.

Iskandar.(2009). Penelitian Tindakan Kelas. Jakarta: GP. Press

Keraf.(2010). Argunebtasi dan Narasi.Jakarta : PT Gramedia Pustaka Utama.

Nafi'ah. (2018). Model-model Pembelajaran Bahasa Indonesia di SD. Jakarta : Ar-Ruzz Media.

Nunung, dkk. (2016). Penerapan Model Pembelajaran Think Talk Write (TTW) Untuk Meningkatkan Keterampilan Menulis Narasi. Universitas Sebelas Maret. Surakarta : Skripsi Tidak Dipublikasikan.

Nurgiantoro.(2010). Penilaian Pembelajaran Bahasa.Yogyakarta : BPFE-Yogyakarta.

Pebriana, P.H. (2017). Peningkatan Keterampilan MenulisPuisi Bebas Menggunakan Pendekatan Kontekstual Siswa Sekolah Dasar. Jurnal Publikasi Pendidikan Volume 7 Nomor 2, Juni 2017. 
Peraturan Pemerintah Nomor 32 Tahun 2013 Pasal 77G

Peraturan Menteri Pendidikan Nasional Republik Indonesia Nomor 22 Tahun 2006 Tentang Standar Isi Untuk Satuan Pendidikan Dasar Dan Menengah. 2006. Jakarta: Diperbanyak oleh PT Armas Duta Jaya.

Riduan \& Sunarto, (2012).Pengantar Statistika untuk Penelitian Tindakan Pendidikan, Sosial, Ekonomi, Komunikasi Dan Bisnis. Bandung: Alfabeta.

Rofi'uddin dan Zuhdi.(2002). Factor kreativitas dalam kemampuasn membaca dan menulis siswa sekolah dasar.Artikel.Bahasa dan Seni Tahun 31.No. 2.Agustus.

Rosidi.(2009). Menulis Siapa Takut. Yogyakarta: Kanisius.

Semi.(2007). Menulis Efektif. Padang: Angkasa.

Shoimin.(2014). Model Pembelajaran Inovatif dalam Kurikulum 2013. Yogyakarta: Ar-Ruzz Media.

Soyomukti.(2016). Pengantar Ilmu Komunikasi. Yogyakarta: ArRuzz Media

Suparno.(2010). Keterampilan Dasar Menulis.Jakarta: Universitas Terbuka

Suyatno.(2009). Menjelajah Pembelajaran Inovatif.Sidoarjo: Masmedia Buana Pustaka.

Sri.( 2012). Metodologi Penelitian Pendidikan. Yogyakarta : Insan Madani.

Taufina.(2016). Mozaik Keterampilan Berbahasa di Sekolah Dasar.Bandung: CV Angkasa.

Tarmizi.(2013). Peningkatan Menulis Puisi Siswa Dengan Teknik Pemodelan Di Kelas VIIID SMP Negeri 19 Kota Bengkulu.pdf. Universitas Bengkulu. 